\title{
High resolution stratigraphy using well logs to identify turbidite stages in the Massapê oil field, Recôncavo Basin, Brazil.
}

Antonio Fernando Menezes Freire ${ }^{1 *}$, Gabriel Fernando Rocha dos Santos ${ }^{1}$, Carolina Ferreira da Silva ${ }^{1}$, Henrique Cavalcanti Pequeno ${ }^{1}$, Ingra Pinto Martins Leal ${ }^{1}$, Wagner Moreira Lupinacci' ${ }^{1}$, Roberto Salvador Francisco d'Ávila².

${ }^{1}$ Universidade Federal Fluminense - UFF

${ }^{2}$ Petróleo Brasileiro S/A

Copyright 2019, SBGf - Sociedade Brasileira de Geofísica

This paper was prepared for presentation during the $16^{\text {th }}$ International Congress of the Brazilian Geophysical Society held in Rio de Janeiro, Brazil, 19-22 August 2019.

Contents of this paper were reviewed by the Technical Committee of the $16^{\text {th }}$ International Congress of the Brazilian Geophysical Society and do not necessarily represent any position of the SBGf, its officers or members. Electronic reproduction or represent any position of the SBGf, its officers or members. Electronic reproduction or storage of any part of this paper for commercial
of the Brazilian Geophysical Society is prohibited.

\section{Abstract}

The integration of rock and well logs data is fundamental for the interpretation of depositional systems and sequences, a fundamental support for E\&P activities. This approach was applied on the low permeability turbidite sandstones and slurries of the Maracangalha Formation, in the Massapê Oil/Gas Field, Recôncavo Basin. Well-log interpretation allowed the recognition of 23 turbidite stages, and four main facies, all observed in each one of these stages: (a) fine to medium sandstones, with porosities greater than 9\%, being the best reservoirs; (b) silty to very fine sandstone slurry facies, that corresponds to very muddy reservoirs with porosities less than $9 \%$, forming important permeability barriers; (c) siltstones and (d) shale. Turbidite stages appear in the Gamma Rays logs (GR) with funnel, block and serrated log motif patterns, corresponding to dominantly thinning and fining upward signatures, recognized in several wells in the Massapê Field. The detailed correlation of these well-logs showed that these stages are present in the whole field. The mapping of the 3rd and 4th order turbiditic stages, considering the correlation of their four facies, will allow a better location of wells, resulting in a more efficient exploration and production development, capable of increasing the recovery of important oil reserves that still exist in the area, optimizing costs and giving greater robustness to E\&P processes.

\section{Introduction}

The Recôncavo Basin (Fig. 1) represents the aborted branch of the South Atlantic, that evolved during the Mesozoic period and that resulted in the supercontinent Gondwana (Magnavita, 2000). This basin has already produced more than 230 million meters cubic meters of oil equivalent and is expected to produce another 250 million cubic meters. Nowadays, it produces $50,000 \mathrm{bbl} /$ day, that represents approximately $1 / 3$ of its peak production, reached in the early 1970 s.

The adoption of this methodology can bring significant economic results and enhanced oil recovery in wells from many mature fields, not only in Recôncavo Basin, but also other mature basins in the country.

The stratigraphic section corresponds to the Maracangalha Formation, a series of gravity flowsand shales deposits in a lacustrine environment developed in a rift setting during the Valangilian (Upper Rio da Serra local stage - Silva et al., 2007). Sandstone turbidites are the main reservoirs, which can be subdivided into Caruaçu (clean sandstones) and Pitanga (muddy sandstones) members. These sandstones were deposited by turbidite currents and slurry flows, associated to the tectonic movement in the basin and climatic variations that conditioned the ups and downs of the deep lake "Maracangalha" and variations of flow regimes.

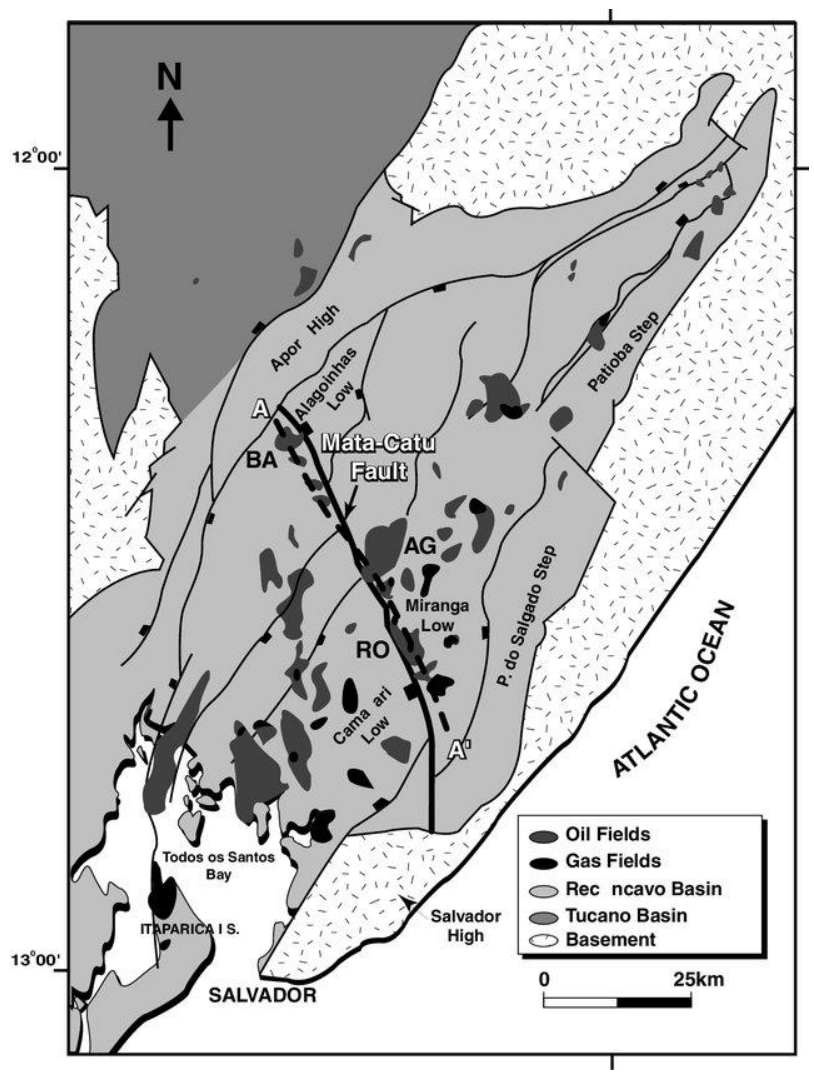

Figure 1: Location map of Recôncavo Basin, NE Brazil, showing the main oil and gas fields and the main structural features. From Magnavita (2000). 
Sandstones of the Pitanga and Caruaçu Members are important gas and oil producers in the Recôncavo Basin. Although they form packages with considerable thickness, such sandy bodies display difficult lateral correlation, and poor lateral and vertical continuity, resulting in discontinuous reservoir bodies and, consequently, more costly and complex oil and gas production. Magnavita et al. (2005) concluded that the Pitanga Member is represented by more clayey sandstones, which were deposited by debris flows, while the Caruaçu Member is represented by sandstones, deposited on delta fronts, slides, slumps, turbidites channels or lobes, the best reservoirs.

The Massapê Field (Fig. 2) is located about $20 \mathrm{~km}$ from the Camaçari Petrochemical Complex, with an area of $23.96 \mathrm{~km}^{2}$. The field produces both oil and gas and is very important for the local economy of the city of São Sebastião do Passé, State of Bahia, approximately $45 \mathrm{~km}$ north of its capital, Salvador.

The main reservoirs of the field are the sandstones of the Maracangalha Fm. - Caruaçu Mb., which produces good quality oil of $38^{\circ} \mathrm{API}$, and account for $93 \%$ of the In-Place Oil Volume (VOIP) and $94 \%$ of its current oil production. The average porosity ranges from $13 \%$ to $15 \%$ and the permeability between 1 and $7 \mathrm{mD}$. The rest of the production comes from the reservoirs of Pojuca Fm. (Cambuqui sandstones, Santiago-1, Santiago-2 and Araçás) and the sandstones of the Marfim Fm. (http://www.anp.gov.br/images/planos_desenvolvimento/ Massape.pdf, 2015).

The integration of rock and well log data was applied on the low permeability turbidite sandstones and slurries of the Maracangalha Formation, in the Massapê Oil/Gas Field, Recôncavo Basin (Fig. 2). High resolution stratigraphy concepts were applied on the three production zones, named Caruaçu-1 (CR-1), Caruaçu-2 (CR-2) and Caruaçu-3 (CR-3), existing in the Massapê Field. Freire et al. (2018) detected 23 turbidite stages using well-logs of 56 exploratory and developing wells. In all of them, the Gamma Ray (GR) log shows an increment in radioactivity/shale content in the upward direction, related to the finning and thinning upward trend associated to the decreasing energy of the flows.
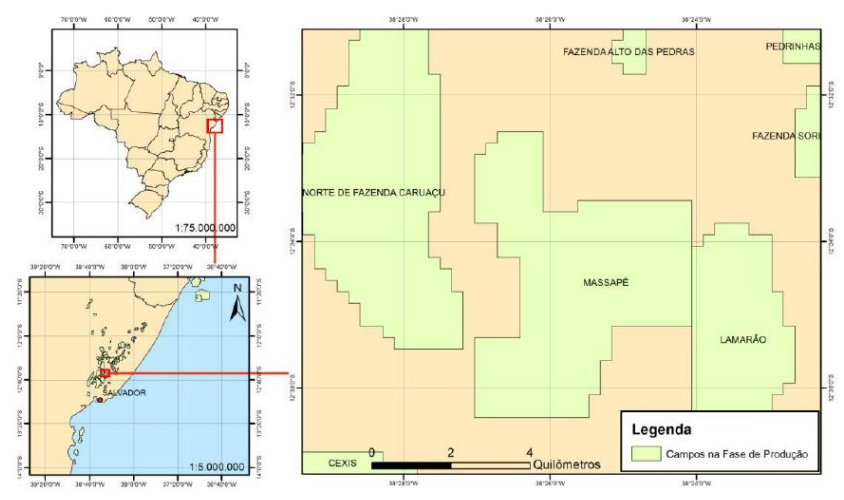

Figure 2: Location map of Massapê Oil/Gas Field in the Recôncavo Basin, NE Brazil. Modified from ANP/BDEP WebMaps (2018).

\section{Method}

This work plans to understand and refine the reservoir zonation in the Massapê Oil/Gas Field, using high frequency stratigraphy concepts proposed by Mutti and Normack (1991).

The following methodology was applied to achieve aim:

- Import of logging curves, provided by BDEP / ANP for academic purposes, for the Interactive Petrophysics (IP) software;

- Quality control of curves and calculation of DRDN parameter:

$$
D R D N=\left(\frac{R H O B-2}{0,05}\right)-\left(\frac{0,45-N P H I}{0,03}\right)
$$

where, RHOB is the density measured at a depth, and $\mathrm{NPHI}$ is the neutron porosity measured in the same depth;

- Logfacies interpretation, based on the following criteria: DRDN $\ll 0$ (sandstone); DRDN $\leq 0$ (slurry); DRDN $\geq 0$ (siltstone); DRDN $>0$ (shale).

- Recognition of turbidite stages according to Mutti and Normack (1991) concepts. It was possible to identify the presence of four logfacies.

- Logfacies correlation between the wells.

\section{Results and Discussion}

The geological interpretation of well logs, calibrated with rock data, allowed the recognition of 23 turbidite stages (Fig. 3):

CR-1 $\rightarrow 12$ turbidite stages (with sand/shale ratio about 50);

CR-2 $\rightarrow 6$ turbidite stages with higher sand/shale ratio, suggesting more sandy and higher volume flows, resulting in amalgamated beds due to increased tectonics and sediment supply phases, possibly associated to higher frequency of intense rains;

CR-3 $\rightarrow 5$ turbidite stages (with intermediate sand/shale ratio, between CR-1 and CR-2).

In each one of the 23 turbiditic stages, four logfacies were observed: (a) Sandstone, composed of fine to medium sandstones, with porosities greater than $9 \%$, being the best reservoirs. Clean sandstones are interpreted as the sedimentation within turbidite channel deposits, usually occupying the base of the turbidite stage; (b) Slurry deposits, composed of very fine extremely clayey sandstones with porosities ranging from $5 \%$ to $9 \%$, forming important permeability barriers; (c) Siltstone and (d) Shale.

The turbidite stages appear in the GR logs as having a thinning and finning upward pattern, recognized in several well-logs in the Massapê Field (Figure 4), possibly corresponding to the backstepping of the turbidite stage. 


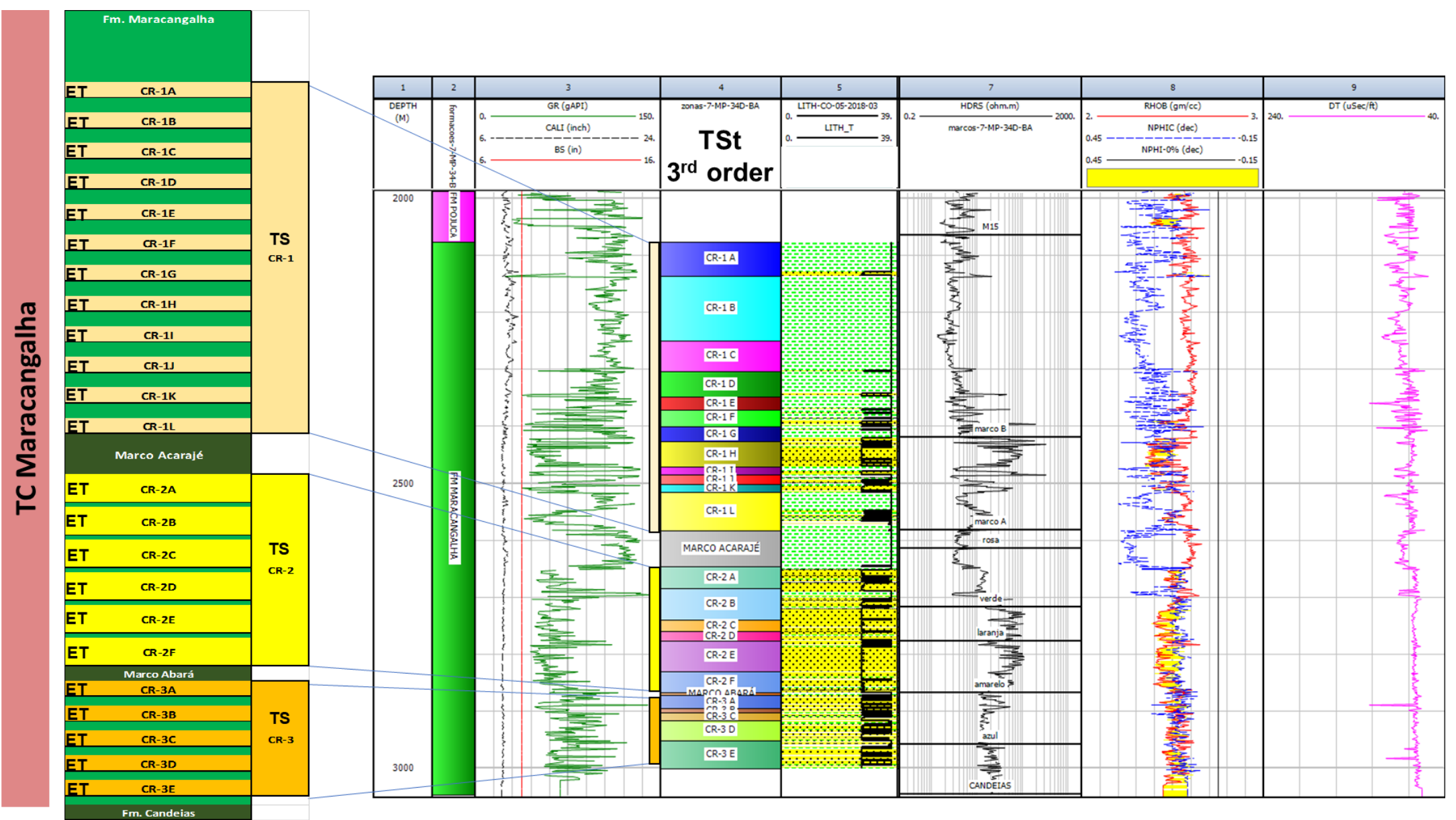

Figure 3: Recognition and interpretation of the 23 turbidite stages, using logs of a well in the Massapê Oil/Gas Field, Recôncavo Basin. TC = Turbidite Complex; TS = Turbidite System; TSt $=$ Turbidite Stage. 


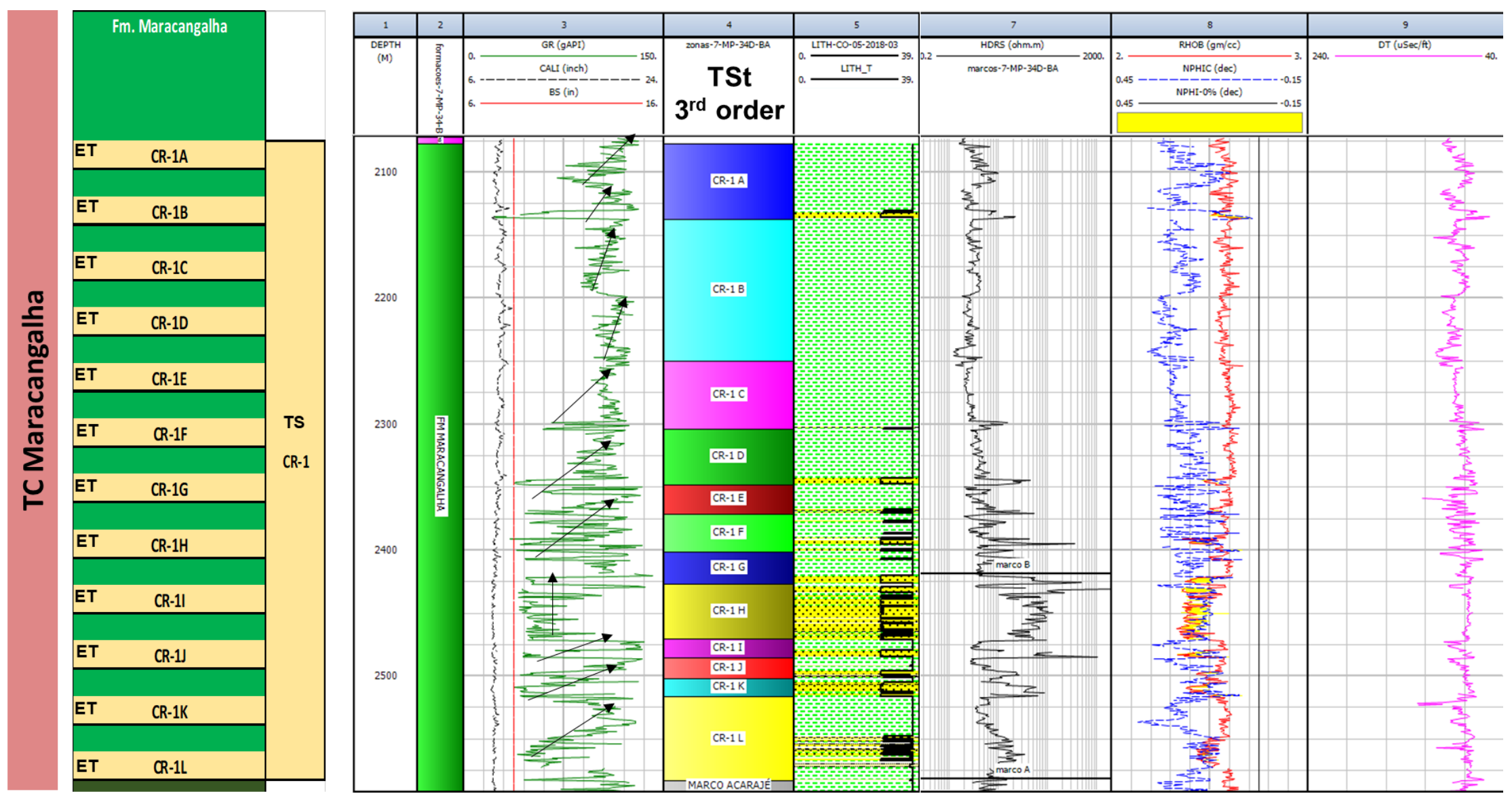

Figure 4: Recognition and interpretation of fine upward cycles controlling the turbidite stages. $\mathrm{TC}=$ Turbidite Complex; TS = Turbidite System; TSt $=$ Turbidite Stage . 
Well-logging correlation of these wells, showed that these turbidite stages are present in the whole field, and can be mapped and recognized in the scale of well logging (logfacies). The 23 turbidite stages can be recognized as $3^{\text {rd }}$ or $4^{\text {th }}$ order bodies, composing three $2^{\text {nd }}$ order turbiditic systems, identified in the Massapê Field as CR-1, CR-2 and CR-3 zones, all forming part of the Caruaçu Mb., Maracangalha Fm.

The Acarajé and Abará markers can be related to moments of tectonic quiescence, with little movement of faults, and/or periods of aridity, with low sedimentary influx to the Recôncavo paleolake. In both cases there would be a lack of a trigger to initiate the turbidity currents that generated of the turbidite reservoirs of the Massapê Field.

Maracangalha Formation is considered, in this study, as a Turbidite Complex (CT) of $1^{\text {st }}$ order. This means that deposition was affected by basin-scale sedimentation disruptions (unconformities), produced by base-level variations of long periods. Probably, the tectonic was the main control for this $1^{\text {st }}$ order depositional pattern.

The reservoir zonation identified as CR-1, CR-2 and CR-3 are interpreted as $2^{\text {nd }}$ order events, and could be originated by variations of the base level of short period and of tectonic activities that produce changes in the sedimentation, however do not generate regional unconformities, but could generate local ones.

Higher-frequency changes in the processes of deposition and erosion, can be considered as $3^{\text {rd }}$ order events, while facies association can be interpreted as $4^{\text {th }}$ order events, possibly related to sediment supply variations, controlled by climatic oscillations.

Both $3^{\text {rd }}$ and $4^{\text {tf }}$ order events are here interpreted as the turbidite stages, characterized by turbidite channels in the base, followed to the top and flanks by slurries, siltstones and shales. The resulting architecture is that every turbidite stage has a finning upward pattern, with increasing heterogeneity to the top and this can be identified when using the association of GR and DRDN curves.

\section{Conclusions}

This study presents the identification of 23 turbidite stages in the Massapê Gas/Oil Field, named here as CR$1 \mathrm{~A}$ to $\mathrm{CR}-1 \mathrm{~L}$; CR-2A to CR-2F; and CR-3A to CR-3E, from the topo to the bottom. The correct identification of the depositional pattern and it's correlated well-log signatures, allows the mapping of $3^{\text {rd }}$ and $4^{\text {th }}$ order turbidite stages. This predictive scheme, considering the origin of the flows and its position in each cycle/stage, their vertical and lateral facies distribution, will allow a better location of wells in the best reservoir facies. This results in a more efficient exploration and production, increasing the enhanced oil/gas recovery and cost optimization, giving greater robustness to the E\&P processes.

\section{Acknowledgments}

To BDEP/ANP for providing data to perform this work;

To Petrobras for the financial support for this study;

To Dr. Pierre Muzzi Magalhães and Prof. Roberto Tinterri, pioneers in the interpretation of slurry flows in these units.

\section{References}

Freire, A.F.M.; Pequeno, H.C.; Lupinacci, W.M.; Santos, G.F.R.; Ramos, M.M.; Neves, I.A.; Silva, C.F.; Facchinetti, Y.A. (2018). Estratigrafia de alta resolução em estágios turbidíticos de $3^{\mathrm{a}}$ e $4^{\mathrm{a}}$ ordens do Membro Caruaçu da Formação Maracangalha, no Campo de Massapê, Bacia do Recôncavo. Trabalho oral apresentado no 49ํㅡㄹ Congresso Brasileiro de Geologia, Rio de Janeiro.

Magnavita, L. P., 2000. Deformation mechanisms in porous sandstones: implications for development of fault seal and migration paths in the Recôncavo Basin, Brazil, in M. R. Mello and B. J. Katz, eds., Petroleum systems of South Atlantic margins: AAPG Memoir 73, p. 195-212.

Magnavita, L.P.; Silva, R.R.; Sanches, C.P. (2005). Roteiros Geológicos: Guia de Campo da Bacia do Recôncavo, NE do Brasil. Boletim de Geociências da Petrobras, v.13 (2), p. 301-334.

Mutti, E.; Normack, W.R. (1991). An integrated approach to the study of turbidite systems. In Weimer, P. and Link, M.H. (eds) Seismic facies and sedimentary processes of submarine fans and turbidite systems. Frontiers in Sedimentary Geology, Springer, ch.4, p. 75106.

Mutti E.; Tinterri, R.; Remacha, E.; Mavilla, N.; Angella, S.; Fava, L. (1999). An Introduction to the analysis of ancient turbidite basins from na outcrop perspective. AAPG Course Note Series \#39, p. 1-61.

Silva, O.B.; Caixeta, J.M.; Milhomem, P.S.; Kosin, M.D. (2007). Bacia do Recôncavo. Boletim de Geociências da Petrobras, v.15 (2), p. 423-431. 